\title{
Effectiveness of an innovative community-based breast cancer awareness workshop
}

\author{
A Al-Shammari", A Al-Dahlawi, A Nurhussen, S Obeidat, M AbouSaleh, S Al-Jazairy, MH Rajab \\ From International Conference for Healthcare and Medical Students 2011 \\ Dublin, Ireland. 4-5 November 2011
}

\section{Introduction}

Breast cancer is the second leading cause of cancer related death in women. Currently, few women in Saudi Arabia get screened for breast cancer. A recent study found a gap between awareness and the practice of breast self-exam (BSE), and emphasized the need for community-based awareness programs. The main objective of this study was to assess the effectiveness of an innovative communitybased breast cancer awareness workshop in increasing the level of confidence in performing BSE in Saudi women.

\section{Methods}

An innovative community-based breast cancer awareness workshop was designed and subsequently conducted in two locations within the City of Riyadh during the months of March and April 2010. The workshop included different techniques that were designed based on neuro-linguistic programming (NLP), which targets three types of learners: visual, auditory, and kinesthetic. A two-part (before and after) questionnaire was used to assess the effectiveness of the workshop in increasing the level of confidence in performing breast self-examination and to measure participants' satisfaction with workshop content and execution. The study was a non-randomized, pre-post design. Data were analyzed using McNemar test. A p $<0.05$ indicated a statistical significance.

\section{Results}

A total of 89 women participated in the two workshops; $74 \%$ were of Saudi nationality and the rest were mainly from neighboring Middle Eastern countries. Sixty-six percent of participants were married, $62 \%$ were college educated, and $77 \%$ were over 26 years of age. At Baseline, $98 \%$ of study participants reported that early detection of breast cancer is very important to them as it improves

$$
\text { Alfaisal University, College of Medicine and Zahra Association for Breast }
$$$$
\text { Cancer, Saudi Arabia }
$$

the chances of successful treatment. In relation to breast self exam (BSE), 69 participants (78\%) reported knowing how to perform the BSE, out of which $43 \%$ reported performing it once per year. At baseline only $15 \%$ of participants reported being confident in performing BSE compared to $59 \%$ after completing the workshop, $(\mathrm{p}<0.00)$. At the end of workshops, 94\% of the participants evaluated the workshop as being excellent and 91\% reported that the workshop met their expectations.

\section{Conclusions}

Based on the survey results, the community-based awareness workshop employed was effective in increasing the level of reported confidence in performing BSE among the study participants.

Published: 9 July 2012

doi:10.1186/1753-6561-6-S4-O25

Cite this article as: Al-Shammari et al:: Effectiveness of an innovative community-based breast cancer awareness workshop. BMC Proceedings 2012 6(Suppl 4):O25.

Submit your next manuscript to BioMed Central and take full advantage of:

- Convenient online submission

- Thorough peer review

- No space constraints or color figure charges

- Immediate publication on acceptance

- Inclusion in PubMed, CAS, Scopus and Google Scholar

- Research which is freely available for redistribution

\section{Biomed Central}

(c) 2012 Al-Shammari et al; licensee BioMed Central Ltd. This is an Open Access article distributed under the terms of the Creative Commons Attribution License (http://creativecommons.org/licenses/by/2.0), which permits unrestricted use, distribution, and reproduction in any medium, provided the original work is properly cited. 